\title{
The (Science Diplomacy) Origins of the Cold War
}

DOI:

10.1525/hsns.2020.50.4.411

\section{Document Version}

Final published version

Link to publication record in Manchester Research Explorer

\section{Citation for published version (APA):}

Turchetti, S. (2020). The (Science Diplomacy) Origins of the Cold War. Historical Studies in the Natural Sciences, 50(4), 411-432. https://doi.org/10.1525/hsns.2020.50.4.411

\section{Published in:}

Historical Studies in the Natural Sciences

\section{Citing this paper}

Please note that where the full-text provided on Manchester Research Explorer is the Author Accepted Manuscript or Proof version this may differ from the final Published version. If citing, it is advised that you check and use the publisher's definitive version.

\section{General rights}

Copyright and moral rights for the publications made accessible in the Research Explorer are retained by the authors and/or other copyright owners and it is a condition of accessing publications that users recognise and abide by the legal requirements associated with these rights.

\section{Takedown policy}

If you believe that this document breaches copyright please refer to the University of Manchester's Takedown Procedures [http://man.ac.uk/04Y6Bo] or contact uml.scholarlycommunications@manchester.ac.uk providing relevant details, so we can investigate your claim.

\section{OPEN ACCESS}




\section{The (Science Diplomacy) Origins of the Cold War}

\section{ABSTRACT}

The US monopoly of information regarding nuclear weapons was one of the distinctive features of the early Cold War. It encouraged US officials to bolster their country's hegemonic role in post-war affairs, something that scholars have previously referred to in terms of "atomic diplomacy." This paper shows that Cold War atomic diplomacy originated in an ancestral form of what we call today "science diplomacy," distinctive of wartime allied relations during WW2. It first explores how science became a distinctive feature of wartime diplomacy by looking at agreements regarding exchanges of information and collaboration that shaped the relations between wartime allies (US, UK, and the Soviet Union). It then shows that their signing (and, at times, their rejection) eventually paved the way to conflicting views within allied administrations on what to share, making their officials less inclined to pool more knowledge toward the end of WW2. In conclusion, US monopolistic stances and atomic diplomacy originated in these disagreements, also marking the demise of wartime science diplomacy.

This essay is part of a special issue entitled Science Diplomacy, edited by Giulia Rispoli and Simone Turchetti.

KEY WORDS: atomic diplomacy, science diplomacy, monopoly, WW2, exchange of information

What would have happened if at the end of the Second World War the United States had agreed with British and Soviet authorities to share most of its restricted scientific knowledge-including that on the atom bomb? The Cold

${ }^{*}$ Centre for the History of Science, Technology and Medicine (CHSTM), University of Manchester, Simon Building, Mi3 9PL, UK, European Union; simone.turchetti@manchester.ac. uk. I would like to thank Matthew Adamson and the referees for their valuable and useful comments to earlier drafts of this article.

The following abbreviations are used: ASE, Allied Supplies Executive; CAB, United Kingdom Cabinet; FO, United Kingdom Foreign Office; FRUS, Foreign Relations of the United States.

Historical Studies in the Natural Sciences, Vol. 50, Number 4, pps. 4II-432. ISSN I939-I8II, electronic ISSN 1939-182X. (C) 2020 by the Regents of the University of California. All rights reserved. Please direct all requests for permission to photocopy or reproduce article content through the University of California Press's Reprints and Permissions web page, https://www. ucpress.edu/journals/reprints-permissions. DOI: https://doi.org/IO.I525/hsns.2020.50.4.4II. 
War would have been a completely different affair, presumably. And in the world conflict's darkest hours, the option of sharing information with allies, even on what would soon become the most powerful weapon on the planet, was not viewed as such a remote possibility in Washington DC. In 1944, two most influential science administrators, Vannevar Bush and James Bryant Conant, sponsored sharing information on the atom bomb as a way to remove the threat that nuclear weapons posed to world peace. They thus prepared a memorandum for the US Secretary of War, Henry L. Stimson, which argued for establishing a new international regime based on sharing the knowledge available within the alliance. In particular, their document vouched support for "free interchange of scientific information," indicating it as "a great step forward in removing some of the dangers to civilization."

Following its filing, however, US officials agreed to keep this information secret so that their country alone could take advantage from it, and use it to build a global monopoly on nuclear weapons. At the Potsdam peace conference of August 1945, the US President Harry Truman referred to the availability of this new weaponry in discussions with the UK Prime Minister Winston Churchill and the Soviet leader Josef Stalin. At least up until the first Soviet atomic test of 1949, the US administration sought to use atomic weapons (and the relevant knowledge) as a diplomacy device to strengthen their country's position in world affairs, especially vis-à-vis the Soviet Union. Historians Gar Alperovitz and Barton J. Bernstein have even contended that the atomic bombing of Hiroshima and Nagasaki aimed to display the power of the new weapons available only to the US to bolster its "atomic" diplomacy, rather than to end the conflict with Japan. ${ }^{2}$

The debate on sharing atomic information evolved in the post-war years, further increasing the distance between those who wished the US to retain a monopoly on nuclear knowledge and products, and those who instead hoped to establish an international information-sharing regime. But in its evolution,

I. V. Bush and J. B. Conant, "Salient Points Concerning Future International Handling of Subject on Atomic Bomb," 30 September 1944, Top Secret, US National Archives and Records Administration (NARA); http://www.nuclearfiles.org/menu/library/correspondence/bushconant/9.30.1944.pdf (accessed June 2020).

2. Gar Alperovitz presented the thesis in Atomic Diplomacy: Hiroshima and Potsdam (New York: Simon \& Schuster, 1965). On the atomic diplomacy debate, see also: J. Samuel Walker, "The Decision to Use the Bomb: A Historiographical Update," Diplomatic History I4, no. I (1990): 97-II4; Barton J. Bernstein, "The Atomic Bombing Reconsidered," Foreign Affairs (Jan/ Feb 1995); B. Bernstein, "Roosevelt, Truman and the Atomic Bomb, 194I-1945," Political Science Quarterly 90 (1975): 23-29. 
this debate re-ignited an already existing controversy over wartime agreements regarding the pooling of scientific information useful to the war effort. US, Soviet, and British diplomacies had spent a long time drafting and negotiating international treaties that defined what their allied scientific teams involved in the war effort should share, and what instead was not open to exchange. These agreements set the scene for the ensuing dispute on atomic information sharing that was distinctive of the early Cold War years.

Although we know a great deal about this dispute, its wartime antecedent has never been sufficiently explored in the existing literature. There are studies discussing aspects of its history, ${ }^{3}$ but few scholars have attempted so far to examine how the wartime diplomacy talks leading to the signing of treaties on the exchange of scientific information influenced allied relations, and the deriving scientific collaborations, in the events leading to end of the Second World War. Their examination is particularly important to understand the circumstances of post-war atomic diplomacy given that, as Michael Gordin has emphasized, we should not take for granted that US planners responsible for making decisions about information sharing had an appreciation of the special nature of atomic weapons. They seemingly treated them in line with existing policy regulating allied relations-hence looking at the existing agreements as the normative framework for their decisions. ${ }^{4}$

The study of published and untapped archival documents regarding diplomatic negotiations within the "grand alliance" that led to the signing of these agreements actually reveals that they represented a defining feature of tripartite relations, mobilizing a number of officers, diplomats, and scientists in government departments, research organizations, embassies, and consulates. ${ }^{5}$ Suggestively (and contributing directly to the aims of this collection), the archival

3. Ronald W. Clark, Tizard (London: Methuen \& Co., 1965); Ferenc Morton Szasz, British Scientists and the Manhattan Project: The Los Alamos Years (Basingstoke, UK: Macmillan, 1992); Donald H. Avery, The Science of War: Canadian Scientists and Allied Military Technology during the Second World War (Toronto: University of Toronto Press, I998); E. H. Beardsley, "Secrets Between Friends: Applied Science Exchange Between Western Allies and the Soviet Union during World War II," Social Studies of Science 7 (1977): 447-73; George C. Herring Jr., Aid to Russia, I94I-1946: Strategy, Diplomacy, the Origins of the Cold War (New York: Columbia University Press, 1973).

4. Michael Gordin, Five Days in August (Princeton, NJ: Princeton University Press, 20I4), xv.

5. In particular, papers on the exchange of technical information available in the Foreign Relations of the United States (FRUS) archive, https:/uwdc.library.wisc.edu/collections/FRUS/ (accessed July 2020); of the UK Foreign Office (FO) and Cabinet (CAB) available at The National Archives, Kew Gardens, London. 
records show these talks to have represented an ancestral form of what we call today "science diplomacy." They mobilized both diplomats and scientists alike in the promotion of scientific exchanges and collaborative work between allied countries, also setting the normative framework for these exchanges to take place.

In the received wisdom, the term "science diplomacy" identifies the promotion of scientific collaborations and exchanges as a way to establish or improve cooperative and cordial relations between nations. ${ }^{6}$ Being a concept of recent coinage, however, its ancestry has yet to be fully explored, although the existing accounts tend to emphasize past cases in which this promotion brokered peaceful relations between countries. ${ }^{7}$ Conversely, cases of wartime coordination in military R\&D do not feature in this literature, even though this coordination propelled international scientific collaborations too, and, in turn, wartime alliances.

This paper shows that inscribing past cases of coordination as forerunners of current science diplomacy projects would considerably enrich our understanding of this new phenomenon. It would, first, reveal that practical, and especially technological, applications deriving from scientific collaborations represented a decisive factor either propelling or stifling these avant-la-lettre science diplomacy schemes. It would also suggest paying greater attention to the normative features of these initiatives, since they show that international scientific exchanges, at least during wartime, often followed tense diplomatic negotiations that set the boundaries for what was exchangeable and what was not. An examination of science diplomacy's ancestry that comprises these critical elements of historical analysis would thus place greater emphasis on

6. Royal Society and American Association for the Advancement of Science, New Frontiers in Science Diplomacy: Navigating the Changing Balance of Power (London: Royal Society, 2010); https://www.aaas.org/sites/default/files/New_Frontiers.pdf (accessed June 2020). A critical uptake of this interpretation is in Peter D. Gluckman, Vaughan C. Turekian, Robin W. Grimes, and Teruo Kishi, "Science Diplomacy: A Pragmatic Perspective from the Inside," Science and Diplomacy (2018); https://www.sciencediplomacy.org/article/2018/pragmatic-perspective (accessed July 2020). While recalling this conceptual fluidity, Charlotte Rungius et al. have noted that science diplomacy is not "a classical analytical object," but a "seeming indispensable reference to the changing role and relevance of science in world politics"; Charlotte Rungius, Tim Flink, and Alexander Degelsegger-Márquez, "Using Science for/in Diplomacy for Addressing Global Challenges," $\mathrm{S}_{4} \mathrm{D}_{4} \mathrm{C}$ Report D2.2, June 2018, https://www.s4d4c.eu/wp-content/ uploads/20I8/o8/S4D4C_State-of-the-Art_Report_DZHW.pdf (accessed July 2020).

7. Vaughan P. Turekian and Norman P. Neureiter, "Science and Diplomacy: Past as Prologue," Science and Diplomacy I, no. I (2012). 
new hybrid networks comprising both scientists and diplomats responsible for elaborating these normative frameworks, and for administering the deriving flows in the international circulation of scientific knowledge from within the realm of state bureaucracies. ${ }^{8}$

This paper exemplifies the merits of such an approach by focusing on allied relations in a transnational historical perspective. ${ }^{9}$ It first shows how during WW2, diplomatic and scientific personnel dealt with the problem of exchange of scientific information, thus promoting bilateral treaties among the three allied powers. It then details how they came to support competing views on what knowledge to share, thus rejecting plans for a tripartite agreement on information sharing. This divergence of opinion affected trilateral relations, even informing the set of decisions regarding the post-war administration of atomic knowledge as a closely guarded secret.

\section{AGREEING TO POOL INFORMATION (TWICE)}

Wartime US/UK relations gravitated around the issue of exchange of scientific and technical information-often a key item in bilateral talks. Truman's predecessor, President Franklin Delano Roosevelt, did not wait for the Japanese attack to Pearl Harbor of December 7, I94I, or the US entry into the conflict, to contribute to assist its future WW2 allies through the provision of restricted scientific and technical knowledge. The previous March he signed the LendLease Act, which enabled Britain to receive military supplies to fight Axis nations. The decision overlapped an even more important act to assist Britain, which became the linchpin of Anglo-American relations: in June I940,

8. Elizabeth Crawford, Terry Shinn, and Sverker Sörlin defined this type of international collaboration in science as state-led or bureaucratic, rather than scientists-led or spontaneous, in "The Nationalization and Denationalization of the Sciences: An Introductory Essay," in E. Crawford, T. Shinn, and S. Sörlin (eds.), Denationalizing Science: The Context of International Scientific Practice (Dordrecht: Springer Netherlands), I-37, on 23-25. Cases of scientists-led international activities are covered in Robert Fox, "Science Without Frontiers: Cosmopolitanism and National Interests in the World of Learning, I870-1940" (Corvallis: Oregon State University Press, 20I6); Daniel J. Kevles, "'Into Hostile Political Camps': The Reorganization of International Science in World War I," Isis 62, no. I (197I): 47-6o.

9. On the transnational history of science, see: Simone Turchetti, Néstor Herran, and Soraya Boudia, "Have we ever been 'transnational'? Towards a history of science across and beyond borders," British Journal for the History of Science 45, no. 3 (2012), 319-36; John Krige (ed.), How Knowledge Moves: Writing the Transnational History of Science and Technology (Chicago: Chicago University Press, 2019). 
Roosevelt agreed with Britain's PM Winston Churchill to share technical information useful to the war effort. ${ }^{10}$ The proposal led, the following September, to a mission of prominent British scientists, led by the chair of the UK Aeronautical Research Committee Henry Tizard, to Washington DC. Just as the Battle of Britain reached its climax, Tizard agreed to exchange information on research outlined in UK facilities in the hope of establishing greater collaboration with US research organizations and developing new weaponry allowing Britain to win the conflict. ${ }^{11}$

Following the instructions received from Churchill, Tizard even agreed to go beyond a bargaining (quid pro quo) basis and offer information without asking for similar releases in return. The mission led to pool information on key radio-engineering components useful to radar development (cavity magnetron) and other items (Merlin engine; proximity fuse). Accompanied by two former pupils of the late Ernest Rutherford at the Cavendish laboratory, Patrick M. S. Blackett and John Cockcroft, Tizard also disclosed the details on recent studies on atomic energy completed in the UK that would instigated further research in the US. From March 1940, a memorandum written by the German refugee physicists Otto Frisch and Rudolf Peierls explored the feasibility of an explosive device releasing atomic energy. Tizard had instructed setting up a committee deceivingly named MAUD and chaired by the Cambridge physicist George Thomson, to further these investigations. The secretly codenamed British atomic energy project, Tube Alloys, thus ensued, while Tizard and his colleagues now disclosed to the administrators of the US National Defense Research Committee (NRDC), including its chairman Vannevar Bush, details about these recent findings in the realm of atomic energy. ${ }^{12}$

The Tizard mission was a distinctive science diplomacy exercise since the talks set British and US wartime research efforts on a convergent path and catered for future collaboration. A new office devoted to regulate these exchanges was set up at the UK embassy in Washington DC. More visits of UK scientists to the US (and vice versa)—also regulated through the release of visas

Io. Clark, Tizard (ref. 3), 254.

II. Szasz, British Scientists (ref. 3), 7.

I2. Beardsley, "Secrets Between Friends" (ref. 3), 449. See also Clark, Tizard (ref. 3), 249, and Margaret Gowing, Britain and Atomic Energy, 1939-1985 (Basingstoke, UK: Palgrave Macmillan, 1982). On the disputed meanings of the name identifying the committee Thomson chaired see Gowing, ibid., 45, and Wikipedia, "MAUD Committee," under "Organisation," https://en. wikipedia.org/wiki/MAUD_Committee (accessed Jul 2020). 
and other documentation-followed at least until 1942, when the US Army took over control of the atomic project and set it up with the codename Manhattan Engineering District. This led to restrictions to scientific exchanges and put the possibility of broader US/UK scientific collaborations in jeopardy. ${ }^{13}$

Churchill sought to counter these restrictions while preparing bilateral talks due to take place at the Washington Conference of May I2-25, 1943. "Interchange of scientific information" now featured as a prickly item in the diplomatic agenda and kept many officials in both diplomatic corps busy. Churchill complained to Roosevelt's special advisor Harry Lloyd Hopkins that US Army officials would not let scientists employed in the Manhattan project share information with British colleagues, thus preventing broader synergies between the two countries now at war with Axis forces. ${ }^{14}$

The complaints concealed other divisive issues. Although Hopkins emphasized that these developments did not entail a breach of the existing US/UK agreement, Churchill stressed that such a stance would prevent closer scientific relations. Hopkins alerted Bush (now director of the wartime organization that replaced the NRDC, the Office of Scientific Research and Development, OSRD), and Bush, like Hopkins, rejected the complaint. He actually resented the UK government for separately agreeing to develop Tube Alloys with Canada's National Research Council and the "Free French" scientists (i.e., the group of scientists opposing the Vichy regime as part of the Free French Forces). As Bush knew already, a joint atomic energy laboratory was being set up at the University of Montreal; eventually the whole Anglo-Canadian(-French) enterprise moved to a new laboratory set up in Chalk River. ${ }^{15}$

Preparation for the Quebec conference (August 14-24, 1943) helped to address the differences between US and UK diplomats and led to new negotiations in the recognition of the importance of scientific collaboration to their countries' relations. Conflicts on intellectual ownership played a divisive role in the proceedings, but administrators particularly eager to defend rights on new inventions deriving from scientific discoveries, such as the Briton Wallace Akers, were replaced.

13. Szasz, British Scientists (ref. 3), I0-I2.

I4. Churchill to Hopkins, I6 Feb I943, and Hopkins to Churchill, Secret, 24 Feb 1943, Secret, in FRUS (ref. 5), Conferences at Washington and Quebec, 1943, I.

I5. "Recent failure (of full scientific interchange) has been entirely due to British refusal to collaborate ... "; Bush to Hopkins, Re: Interchange on S-I, 3I Mar 1943, Secret, FRUS (ref. 5), Conferences at Washington and Quebec 1943, 6-10. 
The removal facilitated the search for an agreement since one sticky point was reciprocal distrust about the attribution of proprietary rights, especially in light of the industrial interests involved in atomic energy projects. ${ }^{16}$ Akers's dismissal was especially welcome in the US because he was involved with the British chemical giant Imperial Chemical Industries (ICI). ${ }^{17}$ US companies such as DuPont that hoped to profit in the future from recent atomic energy research thus viewed the removal as paving the way to a smoother exploitation of recent discoveries in the US. That said, the question of patents and legal rights to exploitation remained highly controversial throughout this period, with no entrepreneur, official, or diplomat able to find a solution. UK atomic energy patents continued to be filed in the US without any knowledge of whether they would eventually lead to a bilateral (or multi-lateral, given Canada's contribution) agreement. ${ }^{18}$

Notwithstanding the legislative uncertainty on patents, Bush, Stimson, his assistant Harvey H. Bundy, Churchill's science adviser Frederick Lindemann (Lord Cherwell), and the incoming Chancellor of the Exchequer John Anderson drafted a new treaty regulating exchange of information on July 22, 1943, during a meeting at Downing Street.

The diplomatic talks produced a compromise setting the stage for "full and effective collaboration" on future work. ${ }^{19}$ The UK had to give away more, though, and accept that not all the relevant information would be shared. Nevertheless, a handful of British scientists could now be involved in the Manhattan project. From 1944, they worked at the secret scientific laboratory set up in Los Alamos, and their presence there epitomized the success of a long, and at times tense, exercise in science diplomacy. British and US officials elaborated, contingently, other rulings on shared intellectual ownership of new inventions, and shared administration of raw materials and intelligence. The Quebec agreement also catered for separate arrangements with the Canadians

I6. Szasz, British Scientists (ref. 3), I0-I2.

17. Gowing claims that this made him persona non grata; Gowing, Britain and Atomic Energy (ref. I2), I72.

I8. For some of these controversies, see Simone Turchetti, “'For Slow Neutrons, Slow Pay': Enrico Fermi's Patent and the U.S. Atomic Energy Program, I938-1953," Isis 97 (2006): I-27; Alex Wellerstein, "Patenting the Bomb: Nuclear Weapons, Intellectual Property, and Technological Control," Isis 99 (2008): 57-87.

19. Articles of the Agreement Governing Collaboration Between the Authorities of the USA and the UK in the Matter of Tube Alloys, FRUS (ref. 5), The first Quebec Conference, 1943, III7-I9. The draft is outlined in the "Memorandum of Meeting at Io Downing Street on 22 July 1943," Secret, in FRUS (ref. 5), The first Quebec Conference, 1943, 634-36. 
and the Free French scientists, who were also involved on the British side of Tube Alloys. It did not, however, entailed collaborating (or informing) the other wartime allies, the Soviets, or making them privy to atomic energy research. ${ }^{20}$ Why was that?

\section{A RUBBERY RELATIONSHIP}

In recent years, historians have been more inquisitive about wartime relations between the US and the Soviet Union without taking for granted that the prevailing anti-communist sentiment in the US administration prevented exchanges of information, or even collaboration between the two countries. Bradley F. Smith has shown, for instance, that the allies traded a great deal more intelligence than previously assumed. ${ }^{21}$ Moreover, there is a long history of technological assistance between the US and Soviet Russia, extending from agricultural machinery to railroads manufacturing. ${ }^{22}$

It is thus unsurprising that wartime US/Soviet negotiations unfolded in parallel with those discussed in the previous section. From November 194I, drawing on the extension of the Lend-Lease agreement to Russia, US diplomats actually worked toward sharing scientific and technical information of use to warfare activities. In particular, the US ambassador in Russia, William Averell Harriman, persuaded colleagues at the US State Department to start a conversation on an agreement similar to that in place with the UK. The proposal stalled, however, due to opposition from Stimson's office and US Army Intelligence personnel. ${ }^{23}$ This resistance was partly due to distrust, especially since the Soviets had allegedly been difficult in the implementation of Lend-Lease. It also derived from a tendency on both US and USSR sides to see exchanges on a strictly quid pro quo basis. ${ }^{24}$

20. Avery, The Science of War (ref. 3), 2I2. See also Beardsley, "Secrets Between Friends" (ref. 3), 455 .

2I. "East and West were not always as hostile as has been suggested. Nor does it appear that they were as determined to march off into mutual hostility in the summer of 1945 as many Cold War traditionalists and revisionists have maintained"; Bradley F. Smith, Sharing Secrets with Stalin: How the Allies Traded Intelligence, 194I-1945 (Lawrence: University of Kansas Press, 1996), xii.

22. For an overview on this and Lend-Lease, see Albert L. Weeks, Russia's Life-Saver: LendLease Aid to the U.S.S.R. in World War II (Lanham, MD: Lexington Books, 2004), 68.

23. Beardsley, "Secrets Between Friends" (ref. 3), 449.

24. Ibid., and Herring Jr., Aid to Russia (ref. 3), 36. 
What really killed a new agreement, however, was a failed science diplomacy initiative that led to an ongoing quarrel regarding exchanges of information on the industrial chemistry of synthetic rubber. The war had greatly reduced its natural equivalent, and US war planners were desperately looking for details on industrial processes allowing the synthesis of artificial rubber, especially to make military-grade tires. Particularly important to the war effort was the production of BUNA S, a mix of styrene and butadiene that Soviet chemists had succeeded in synthesizing. In February 1942, Soviet officials offered to exchange information on the processes, but their proposition was rejected. ${ }^{25}$ The following summer the refusal caused sensation in the US since Roosevelt appointed a committee chaired by the philanthropist and financier Bernard Baruch to consider how to deal with the scarcity of rubber. The committee (which had James Bryant Conant among its members) was particularly resentful of those responsible for rejecting the Soviet proposition. It called for reestablishing relations to secure scientific exchanges. ${ }^{26}$

The following December, a US mission visited Moscow. Led by Ernest Pittman, president of the leading US chemical company, InterChemical, it failed to secure an agreement (possibly because of Pittman's private interest in these matters). US/USSR talks on synthetic rubber re-opened in July 1943 when, however, US scientists had found an alternative process to produce it. ${ }^{27}$ Bush's advisor Carroll Wilson begrudged that the Russians had "disclosed practically nothing" and they "got more than they gave," 28 a view shared with the head of the US military mission in Moscow. ${ }^{29}$

The rubber incident was a dealbreaker. From then onward, US/Soviet science diplomacy activities and wartime exchanges of scientific and technical information visibly shrunk. This is not surprising, as we have seen that at one point US/UK collaboration had contracted, too. Yet, in contrast with Churchill, Josef Stalin did not show the same enthusiasm for re-negotiating the terms

25. "Digest of the Report by Baruch Committee Offering Rubber Program," New York Times, II Sep 1942.

26. "Had the offer ... been accepted, it is conceivable that plants for producing synthetic rubber by the Russian processes might well be on the way to completion"; ibid.

27. A. Richard, "Interchange of Technical Information with USSR on Synthetic Rubber," Is Jul 1944, FRUS (ref. 5), Europe (USSR), 1944, 1103-05.

28. T.W.J. Taylor, British Central Scientific Office, to Alexander King, UK Ministry of Production, Most Secret, I5 May 1943, in "Exchange of technical information with the Soviet Union," FO 371/36928.

29. John R. Deane, The Strange Alliance: The Story of American Efforts at Wartime Cooperation with Russia (London: John Murray, 1946), 49-50. 
of information sharing with US officials. Nor did he solicit, as we shall now see, support to the treaty signed for pooling information with Britain.

\section{THE SOVIETS SHILLYSHALLY}

A treaty establishing interchange of technical information between Britain and Soviet Russia was signed in September 1942, just as the Baruch Committee report was about to be released. The promise of a treaty to exchange technical information was another exercise in science diplomacy. It was also the classic pill Churchill intended to use to sweeten otherwise sour news regarding allied relations. During the Second Moscow Conference of August I2-I7, 1942, he had to inform an anxious Stalin that the opening of a second front in Europe would not happen soon. He offered to exchange technical information instead.

Churchill's proposition led to a treaty, which took the form of an exchange of notes. The terminology used, "interchange of information on warlike inventions," replicated that of the existing US/UK agreement. Britain and the Soviet Union would "furnish to each other on request all information ... relating to weapons, devices or processes which at present are, or in future may be, employed by them for the prosecution of the war against the common enemy." Stalin's deputy, Vyacheslav Molotov, took responsibility for signing the agreement. ${ }^{30}$

The exchange entailed primarily knowledge on radar equipment, thus ruling out further interactions, especially on atomic energy. However, at some point British officials took into consideration extending the agreement to other items. For instance, one of George Thomson's pupils, the physicist Wilfrid Basil Mann, asked whether the treaty extended to weapons yet to be developed as he was busy negotiating atomic energy provisions in Washington DC and therefore wanted to know what to say if the Soviets asked for information about these weapons. The British government committee set up to deal with inter-alliance exchanges, the Allied Supplies Executive (ASE), addressed Mann's concerns, indicating the need to avoid unsolicited disclosure while authorizing the provision of any other piece of information requested. ${ }^{31}$

30. Exchange of Technical Information with the Soviet Government, War Cabinet W.P. (42) 453, Secret, 8 October 1942, in "Proposed exchange of technical information with the Soviet Union," FO 371/32956. See also Clark, Tizard (ref. 3), 346.

31. Christopher Warner, FO, to P. B. Mair, Ministry of Supply, 30 October 1942, FO $37 \mathrm{I} / 32956$. 
In the first half of 1943, Anglo-Soviet scientific relations flourished. ASE officials even agreed to organize a mission to visit Moscow and thus prompting more collaboration. Indeed, they even instructed to select envoys for the Moscow mission "comparable in quality to members of Sir Henry Tizard's Mission to the USA." 32 The plan, however, stalled due to obstacles from inside and outside Britain. Churchill's science adviser, Lord Cherwell, now vocally objected to giving away more knowledge to the Soviets, and insisted that a future mission should have a strictly limited amount of specific items for release. ${ }^{33}$ Moreover, when US authorities learned about the Anglo-Soviet technical accord, they indicated that they did not know about the treatythus stressing the need to revise existing agreements between US and UK governments. British officials countered these objections by stating that Averell Harriman was present when the UK/Soviet treaty was first proposed, and he was kept informed about later developments. ${ }^{34}$ According to the US officers, it was not him, a renowned advocate of wider exchanges with the Soviets, that UK officials should have consulted, but the top brass at the OSRD. ${ }^{35}$

Preparations for the Tizard mission to Moscow continued but, in light of these objections, slowed down. Moreover, in June 1943, Molotov let UK representatives know of difficulties in assembling a Soviet team of experts to meet them. ${ }^{36}$ Statistical data available to the UK Foreign Office made Tizard even more anxious as they suggested that the treaty had allowed Soviet experts to gain information on British equipment and processes, while its officers had rebuffed requests for information on Soviet products far too frequently. For instance, British officials resented the refusal of details on air expansion turbines designed by the physicist Pyotr Kapitza and other information on artillery equipment. ${ }^{37}$

32. Anglo-Soviet Agreement for the Interchange of Technical Information, ASE Meeting, 30 December 1942, in FO 37I/36927. Tizard is hoping that PM will "give me the same directions" as "when he sent me on a similar mission in the USA in 1940"; Clark, Tizard (ref. 3), 346.

33. Lord Cherwell to Prime Minister, 20 January 1943 in "Exchange of technical information with the Soviet Union," FO 371/36927. See also Beardsley, "Secrets Between Friends" (ref. 3), 450. On Lindemann, see also Adrian Fort, Prof: The Life of Frederick Lindemann (London: Jonathan Cape, 2003).

34. C. Warner, FO, to War Cabinet, February 1943, in FO 371/36927.

35. T.W.J. Taylor of the British Central Scientific Office to King, Most Secret, I5 May 1943, in FO $37 \mathrm{I} / 36928$.

36. From Moscow to FO, I7 June 1943 , in FO 371/36928.

37. "Requests and Disclosures as from 3oth September 1942," in FO 371/36928. See also Beardsley, "Secrets Between Friends" (ref. 3), 467. 
Four days after the signing of the Quebec Agreement, the UK Minister of Production and ASE chairman, Oliver Lyttleton, mothballed Tizard's mission as the Soviets "shilly-shallied" on the British proposition. ${ }^{38}$ At the end of summer, Tizard resigned from his post, disappointed about the failed mission, and in disagreements with Churchill and Lord Cherwell on the directions of wartime research. ${ }^{39}$

Lyttleton now had to deal with one important problem arising from the UK/Soviet technical accord. The troublesome item was its escape clause indicating that in case British authorities denied technical information to the Soviets, they were compelled to offer a reasonable justification for this exclusion. This was a thorny diplomatic issue especially in light of the Quebec treaty regarding atomic energy, which stressed instead that the contracting parties were not entitled to "communicate any information about TUBE ALLOYS to third parties except by mutual consent." ${ }^{40}$ Lyttleton now realized that complying with one international treaty (the one with the Soviets) could have led to breaching the other (the one with the US). If the Soviets asked information about atomic energy, British officials had to disclose, at the very least, the existence of another agreement preventing further disclosures. Not only did this threaten US/UK atomic collaboration, but disclosure, even if just to explain why information should not be released, could also have embarrassed the Americans too, since it would have showed their unwillingness to treat UK and Soviet Russia in the same way in the context of the "grand alliance." Finally, it would have made the Soviets even more reluctant to share information with them. ${ }^{41}$ Unsurprisingly, Lyttleton was now desperately looking to revise the existing agreements. The only viable solution seemed to him a tripartite treaty to replace them.

\section{TRIPARTITE MERRY-GO-ROUND}

British diplomats had envisaged the merits of an agreement granting exchange of scientific and technical information within the grand alliance from as early

38. ASE, Memorandum by the Chairman, 23 August 1943, Secret, in "Exchange of technical information with the Soviet Union," FO 371/36939.

39. Clark, Tizard (ref. 3), 349.

40. Articles of the Agreement Governing Collaboration Between the Authorities of the USA and the UK in the Matter of Tube Alloys (ref. 19), III7.

4I. "We are not required to disclose to Russia ... but we are in the difficulty that if we refuse it is hard to give a reason to the Russians which will not put the Americans in an embarrassing position," ASE, Memorandum by the Chairman, 23 August 1943, FO 371/36939 (emphasis added). 
as December 1942. Yet, also in light of the recent controversy regarding the UK/Soviet treaty, in the summer of 1943, a troubled Lyttleton urged revising the draft prepared for US authorities to include pledging for a tripartite exchange of information. A former member of Tizard's mission, the physicist Patrick Blackett, now sought to address Lyttleton's impasse and prepared a treaty removing the escape clause. If a tripartite was to be agreed, then allied parties could deny information without being at the same time compelled to offer a justification for their denial. ${ }^{42}$

While producing some positive reactions in Washington DC, US authorities eventually rejected Blackett's draft. In October 1943, their colleagues at the UK Joint Mission approached the US State Department with confidence in a future approval. ${ }^{43}$ Lyttleton was also persuaded that the US diplomat responsible for European Affairs, Eldridge Durbrow, would be sympathetic since he had previously shown appreciation for UK efforts to draft a tripartite agreement. Indeed, Durbrow prepared a memorandum agreeable to the proposal and even accepted in principle Blackett's reasoning that such an agreement would have been especially useful in the conflict against Japan since it would have allowed pooling critical information between the allies before the attack. In particular, the Soviets could have benefitted from information on a transponder radar for aerial dropping of forces that would have been particularly effective in the invasion of Manchuria. ${ }^{44}$

But by the end of the month, Durbrow understood the proposal's ulterior motives too: "The UK," the US diplomat wrote, "may be acting to protect US/UK collaboration vis-à-vis the Escape Clause fearing that this collaboration would vanish if the knowledge regarding it is passed on to Soviet Union, even if just to explain why information is withheld." 45 The negative remarks informed the trail of responses that followed in the USA. The UK's ulterior motives outweighed the advantages of a new treaty. In January 1944, US members of the Combined Intelligence Committee raised objections, shortly followed by the US Chiefs of Staff, who believed a tripartite treaty unnecessary.

42. Draft Tripartite Agreement, undated, in FO 371/36929; John Russell to H. Redman, Secret, 22 December 1943, in "Disclosure of information to the Russians," CAB 122/936.

43. From British Joint Services Mission, Washington DC, to FO, Secret, I7 October 1943, in FO 371/36929.

44. Memorandum by Elbridge Durbrow of the Division of European Affairs, 8 Dec 1943, FRUS (ref. 5), The British Commonwealth, Eastern Europe, the Far East, 1943, 792-93.

45. Memorandum by Elbridge Durbrow of the Division of European Affairs, 23 Dec 1943, FRUS (ref. 5), The British Commonwealth, Eastern Europe, the Far East, 1943, 794-96. 
In March, consensus was mounting among ASE members that Blackett's proposal was "dead." 46

Yet Lyttleton also realized that a continuation of the UK/Soviet agreement would threaten the Quebec treaty. He thus instructed letting the Anglo-Soviet technical accord wither away, while Lord Cherwell now reprimanded Blackett for wanting to release more to the Soviets. ${ }^{47}$ "Little of the high-grade information ... relating to more complex and up-to-date equipment" should be made available to the Russians before the end of the war with Germany, Cherwell argued, especially since it was unclear if the Soviets would be involved in the war with Japan. ${ }^{48}$

The ASE continued to release a steady trickle of low-grade information to appease the Soviets and kept the UK/Soviet agreement going without raising the issue of obtaining information in return. Its officials hoped to avoid giving the impression of bargaining, which would have elicited more requests from Soviet Russia. Eventually, they agreed to avoid recalling the terms of the agreement. ${ }^{49}$ In June 1944, as Allied tanks successfully pushed through Normandy for the invasion, paving the way to Germany's defeat, the British government instructed Blackett to share as little as possible with the Soviets. ${ }^{50}$ The following year inquiries regarding espionage networks operating in Cana$\mathrm{da}$ and connected to the Soviet embassy (because of under-cover intelligence operative Igor Gouzenko) informed the British stance. ${ }^{51}$ The government even prevented his leading scientists from visiting Moscow on the 220th anniversary of the Soviet Academy of Sciences. This negative posture actually reversed the

46. R. C. Firebrace, War Office, to R. C. Roy, ASE Secretariat, 2I March 1944, Secret, in "Exchange of technical information with Russia," FO 37I/43284. A tripartite military committee was also proposed but never set up; Deane, The Strange Alliance (ref. 29), 152-53.

47. Other contrasts with Blackett in relation to air and naval strategy are discussed in Fort, $\operatorname{Prof}$ (ref. 33), 274-76.

48. Note by the ASE Chairman, Secret, 23 May 1944, in "Exchange of technical information with Russia," FO 371/43285.

49. "No reference should be made to the Anglo-Soviet agreement"; Chiefs of Staff to British Military Mission in Moscow, 9 July 1944, Top Secret, in "Disclosure of information to the Russians," CAB I22/937.

50. Beardsley, "Secrets Between Friends" (ref. 3), 46r.

5I. A cipher clerk at the Soviet embassy in Ottawa, in September 1945, Gouzenko admitted to security agents of the Royal Canadian Mounted Police to have acquired restricted information thanks to a network of spies operating in Canada. The case famously led to the investigation of UK expert Alan Nunn May, who was employed in Tube Alloys. May was trialled and sentenced to ten years hard labor. See Avery, The Science of War (ref. 3), 228-32; see also S. Turchetti, The Pontecorvo Affair (Chicago: University of Chicago Press, 20I2). 
situation of the previous year, as in 1945 the US administration released more technical information to the Soviets than did the British. ${ }^{52}$

The UK/Soviet bilateral accord on exchanges of information was now as dead as the prospect of a trilateral. But the failed proposal for an exchange of scientific information within the grand alliance also had an impact on the ongoing debate about the exchange of information on atomic energy, since the Manhattan project was about to reach completion. In particular, it stiffened the position of negotiators who might have been open to sharing atomic energy information with the Soviets, but now posited avoiding such an exchange.

\section{FROM SCIENCE DIPLOMACY TO ATOMIC DIPLOMACY}

The realization that atomic weapons would release massive destructive power mobilized scientists who knew about the ongoing Manhattan project and worried about its impact on international affairs. Historians have focused in particular on the Danish physicist Niels Bohr, who spent some time in Los Alamos as a member of the British mission before lobbying for sharing information on atomic energy with the Soviets in order to prepare a regime of international control. The new regime, Bohr argued, needed "openness" in the administration of atomic information at international level, i.e., for all powers to pool knowledge about the bomb to prevent individual nations from singlehandedly using it. ${ }^{53}$

The long history of science diplomacy negotiations and treaties on wartime information sharing offers a valuable explanation as to why Bohr could not persuade the alliance leaders. Ultimately, lawfully exchanging information depended on the existing international treaties. One, the bilateral agreement

52. By the end of 1944, the Americans had released technical details on 246 items, in contrast with the UK, which released only on II. Exchange of Technical Information with the Russians, Top Secret, 31st December 1944, in "Exchange of technical information with the Soviet Union," FO $371 / 47847$.

53. Finn Aaserud, "Niels Bohr's Mission for an 'Open World'," in M. Kokowski, Proceedings of the 2nd ICESHS (Cracow, Poland, 6-9 Sep 2009), 706-09; F. Aaserud, "The Scientist and the Statesmen: Niels Bohr's Political Crusade During World War II," Historical Studies in the Physical and Biological Sciences 30 (1999): I-47. See also Barton J. Bernstein, "Roosevelt, Truman" (ref. 2), 28; Richard Hewlett and Oscar E. Anderson Jr., The New World. A History of the United States Atomic Energy Commission, Vol. I, 1939-1946 (Berkeley: University of California Press, 1962), 335-40; Richard Rhodes, The Making of the Atomic Bomb (New York: Simon \& Schuster, 1986), 530. 
between Britain and Soviet Russia, now embarrassed the British authorities. US officials opposed the other, i.e., the prospective tripartite agreement. Bohr did not know about these treaties and their current circumstances and, regardless of his prestige and authority on scientific matters, could do little to reverse this trend to withhold restricted scientific information. Exchanging information on atomic weapons would have required a broader agreement on the exchange of scientific information, which was exactly what UK and US officials had recently ruled out.

Bohr met with Churchill and Lord Cherwell on May 16, 1944, only days before the science adviser's recommendations for letting the Anglo-Soviet technical accord wither away, and they certainly understood Bohr's proposition as a complication. ${ }^{54}$ His initiative re-vamped the problem of the technical accord's escape clause, since the information he intended to release was exactly about advances in atomic energy research. After the meeting, Bohr sent a memorandum to Roosevelt. In the document he returned to the issue of exchange of information, stating that he wished to prevent "competition between nations" by making "concessions regarding exchange of information." 55

It is true that Bohr found a sympathetic hearing with the scientific director of Los Alamos, Robert Oppenheimer. He also persuaded Bush, as the experience of wartime collaboration convinced the US science administrator that interchange of scientific information provided advantages in the production of new knowledge. Indeed, Bush went on to write the memorandum discussed at the beginning of this paper. ${ }^{56}$ But the memorandum proposal ran counter to the conclusions reached by US military officials regarding a tripartite agreement, and added to the growing anxiety in the US administration about the presence of Soviet spies infiltrating the atomic project. More to the point this article makes, Bohr's proposition would have also entailed a substantial revision of the Quebec agreement-a pillar of wartime science diplomacy.

In September 1944, Roosevelt met Churchill in Hyde Park, and the British Prime Minister, mindful of the rejected tripartite proposal, now recalled the terms of the Quebec treaty. They thus agreed that no information on Tube Alloys was to be made available internationally, and certainly not to the "shillyshallying" Soviets, while also hinting at the possibility of using the atom

54. Fort claims that Lindemann was sympathetic of Bohr's proposal. See Fort, Prof (ref. 33), 312. 55. Niels Bohr's memorandum, July 1944; www.atomicarchive.com/Docs/ManhattanProject/ Bohrmemo.shtml (accessed July 2020) (emphasis added).

56. Rhodes, The Making of the Atomic Bomb (ref. 53), 644-46. 
bomb in the conflict with Japan. Roosevelt also agreed with Churchill to put Bohr under surveillance to prevent him from unlawfully leaking information to the Soviets. ${ }^{57}$

Their instructions aligned with current developments in wartime science diplomacy and, crucially, affected future atomic diplomacy exercises too. At the beginning of 1945 , management of information regarding atomic weapons became a hot topic within the US administration. ${ }^{58}$ The prospect of an atomic knowledge-sharing device within the soon to be established United Nations was discussed in preparation for the Yalta peace conference of February 1945. But since it remained unclear if the Soviets would play a role in the war against Japan, nobody in the US administration wished to elaborate on policy provisions reconsidering information-exchange on a trilateral basis. ${ }^{59}$ Contingently Bush, Conant, and other US officials mothballed plans to disseminating publicly more information about the research carried out at Los Alamos. In particular, an official report on the atomic energy project by Princeton University physicist Henry DeWolf Smith, drafted already in February (a "faded echo of Niels Bohr's appeal for openness," according to historian Richard Rhodes ${ }^{60}$ ), went through several critical revisions by the military director of the Manhattan Project, General Leslie Groves, and others US officials that curtailed critical details before public release.

Roosevelt passed away on April I2, I945, with nothing further decided on trilateral exchanges, and following his death Churchill even more vibrantly opposed the prospect of an agreement. While already in Berlin for the Potsdam peace conference due to start just a few days later, the UK Prime Minister felt compelled to remind Stimson about the reassurance that Roosevelt had given him the previous year about the Quebec treaty terms on the interchange of information. ${ }^{61}$ Stimson thus alerted Roosevelt's successor, Harry Truman, that he had to be particularly careful in providing to Stalin information about the recently completed Trinity test without divulging anything that would breach the existing US/UK treaty. Truman's considerable vagueness in describing to

57. Aide-Mémoire of Conversation Between the President and the Prime Minister at Hyde Park, I8 Sep 1944, Top Secret, I9 Sep 1944, in FRUS (ref. 5), The Second Quebec Conference, $492-93$.

58. Hewlett and Anderson Jr., The New World (ref. 53), 335-40.

59. Deane, The Strange Alliance (ref. 29), 240.

6o. Rhodes, The Making of the Atomic Bomb (ref. 53), 750.

6I. Churchill to the Secretary of War (Stimson), Top Secret and Personal, Berlin, I8 Jul 1945, in FRUS (ref. 5), The Conference of Berlin (the Potsdam Conference), I370. 
Stalin a new US "weapon of unusual destructive force" 62 was thus first and foremost a way to fall in line with the chief wartime treaty regarding exchanges of scientific information - the final act in wartime science diplomacy. Stalin did not reply, though, as the information regarding the new weapon, and the US/UK collaboration on its completion, had already reached him through intelligence channels.

With atomic diplomacy now featuring more in tripartite affairs, international control of atomic energy represented an important, but now subordinate, item in the US diplomacy agenda. Bush and Conant's plea eventually snowballed in the creation of an Interim Committee within the US administration, chaired by Stimson and charged with providing recommendations to Truman about the post-war administration of atomic energy-related information. In its final report, released in the month before the Hiroshima bombing, Committee members pledged for an international control mechanism, but did not endorse plans for disclosing information available to the US alone any time soon. ${ }^{63}$

Bush and Conant now pushed for such a plan to materialize under the aegis of the United Nations. A committee chaired by Dean Acheson and David Lilienthal (and having Bush and Conant as members) set out a US State Department report. Submitted to the United Nations, the document advocated that the new international organization take responsibility for divulging information regarding recent nuclear research. Truman appointed Bernard Baruch, the chairman of the wartime commission that had attempted to seal a deal on exchange of scientific information with the Soviet Union, to represent his country at the United Nations Atomic Energy Commission. Yet the envoy failed again, as the Soviets abstained on his plan to pool atomic information internationally (and Truman did not support him enough either). ${ }^{64}$ The Commission was inactive from 1949 and eventually dissolved in 1952 . By then the US Congress was about to approved a revised version of the Atomic Energy Act, which since 1946 had prevented any exchange of US atomic information with other countries. The act epitomized the US administration's divesting from wartime science diplomacy efforts and aligning with what was later dubbed as "atomic diplomacy."

62. Harry S. Truman, Year of Decisions (Garden City, NY: Doubleday and Company, 1955), 4I6.

63. Hewlett and Anderson Jr., The New World (ref. 53), 36o-6r.

64. Ibid., 6o8-09. 


\section{CONCLUSIONS}

Today we look at science diplomacy as a novel concept paving the way to a deeper understanding of the connections between international relations and scientific collaborations. But diplomatic talks regarding the exchange of scientific information and scientific collaboration are not new. While science diplomacy is an historical phenomenon whose ancestry we have yet to explore in full, this paper shows that there is merit in looking at its past, especially during WW2. Talks on wartime scientific collaboration were similar to current science diplomacy exercises in the sense that they shared the ambition to pooling scientific information and promoting scientific exchanges as a way to unite countries. They differed, however, as they did not necessarily entail peaceful ambitions, and aligned to interests in the national security and defense realms. Then as today, the practice of science diplomacy shaped networks that comprised scientists and engineers (e.g., Tizard, Blackett, Bush, Bohr), state officials (e.g., Stimson, Molotov, Lyttleton), and diplomats (Harriman, Baruch, Durbrow). And during the war these officials worked toward designing binding agreements and legislation especially on what scientific information to share.

The treaties signed in Quebec and Moscow regulated the flow of scientific exchanges between allies and set the boundaries for pooling knowledge within the grand alliance, also paving the way to more scientific collaboration. Partly because of their bureaucratic nature, these agreements facilitated exchanges on a bilateral basis but also, possibly, complicated trilateral ones, especially when they required the consensus of a conspicuous number of national agencies.

The renunciation to comprehensively share scientific knowledge within the grand alliance played an important role in the events leading to the Hiroshima and Nagasaki bombings and the post-war definition of atomic energy legislation. Although there certainly was never was a single "decision" on the bombings, ${ }^{65}$ the Hyde Park diplomacy talks between Churchill and Roosevelt weaved in for the first time the question of whether or not the Soviets ought to know about atomic weapons. The renunciation to pool scientific information within the grand alliance, sanctioned especially by the rejection of a tripartite agreement, further persuaded Stimson and Truman that Stalin should know as little as possible about the bomb. With the US administration on the path of atomic diplomacy, its officials eventually relinquished even the wartime information agreement with the UK. In turn, the proponents of international 
control of atomic energy—such as Bohr, Bush, and Conant—could not succeed in their plans.

The US diplomats' stiffening on the possibility of exchanging more scientific (and even atomic) information may well have depended on the inducting of a new US president in 1945. Roosevelt had committed in Hyde Park to avoid sharing with the Soviets, but kept options open after that. Truman, by contrast, relied more on advisers with an anti-Soviet sentiment, and never reconsidered the information policy set out by his predecessor. ${ }^{66}$ Even so, the evidence herewith disclosed shows that Truman would have faced considerable opposition from the US Chiefs of Staff (and from Churchill, possibly) if he wanted to share more.

Left out of atomic information sharing, the Soviets certainly resented the other allies for boasting the merits of a grand alliance while being selective in making "science diplomacy" agreements. Their sense of disappointment and betrayal may even explain the increase of Soviet-led espionage activities. ${ }^{67} \mathrm{UK}$ officials resented their US colleagues too, although they eventually found a way to restore their "special relationship" during the I950s.

Wartime diplomacy on scientific and atomic exchanges left a visible legacy in competing historical portrayals about the atomic bombings and the end of WW2. Stimson deliberately overlooked the diplomatic talks on information sharing when explaining how the US administration had arrived at the decision to drop the bomb(s) and famously explained it only with the ambition to save the life of invading US forces. ${ }^{68}$ Another chief contributor to wartime talks on information sharing, Blackett, challenged Stimson's version of events and was the first to posit that the atomic bombing of Japan was actually an exercise in atomic diplomacy, running counter to the successful collaborative policy elaborated during wartime diplomacy talks. ${ }^{69}$

66. Bernstein speculates that "had Roosevelt lived, perhaps he would have reversed the policy of secrecy and decided to move towards international control in return for a quid pro quo"; Bernstein, "Roosevelt, Truman" (ref. 2), 3I. On Truman's stances, see also: Peter J. Kuznick, "The Decision to Risk the Future: Harry Truman, the Atomic Bomb and the Apocalyptic Narrative," The AsiaPacific Journal 5 (2007): I-23, on 8; and Bernstein, "The Atomic Bombing Reconsidered" (ref. 2).

67. The available literature treats espionage as distinctive of wartime Soviet administration, rather than something defined by historical circumstances. See, for instance, David Holloway, Stalin and the Bomb (New Haven, CT: Yale University Press), 82, IO3, I35.

68. Henry L. Stimson, "The Decision to Use the Atomic Bomb," Harper's Magazine (Feb 1947): 97-107.

69. P.M.S. Blackett, Military and Political Consequences of Atomic Energy (London: Turnstile Press, 1949). When this book was published, Blackett's colleagues in the US attacked him as an 
Meanwhile, wartime diplomatic negotiations gave rise to two antithetical ways to administer international relations, which became distinctive of the nuclear age. One, "atomic diplomacy," consisted of rejecting the principles of information sharing distinctive of its wartime ancestor while seeking to use the monopoly of information on nuclear weapons as a "hard-power" diplomacy device. The other advocated the need for building peaceful and positive relations between countries through the pooling of knowledge on atomic weapons, internationally, and the intensification of international scientific collaborations on nuclear disarmament. These two interwoven but opposing forms of negotiation brought forward the ambitions of wartime diplomatic work on the exchange of scientific and atomic knowledge, and represented their most visible legacy during the Cold War.

amateur in international affairs, whereas the archival documents discussed in this paper confirm that he was heavily involved in wartime international negotiations. Unsurprisingly, Lord Cherwell attacked him too, thus taking forward a polemic started in the context of the ASE proceedings. Lord Cherwell, "Atomic Bombing: the Decisive Weapon—And Deterrent," The Daily Telegraph, 9 Dec 1948. 